\title{
Validation of a model to estimate climate effects on wheat (Triticum aestivum L.) production in a hydrological basin
}

\author{
Salazar-Solano, Vidal ${ }^{1}$; Moreno-Dena, Jesús M. ${ }^{1 *}$; Rojas-Rodríguez, Isaac S. ${ }^{2}$; \\ De La Torre-Valdez, Hugo C. ${ }^{3}$ \\ 1 Centro de Investigación en Alimentación y Desarrollo A. C., Hermosillo, Sonora, México, C. P. 83304. \\ 2 Universidad de Sonora. Hermosillo, Sonora, México, C. P. 83000. \\ 3 Universidad Estatal de Sonora, Hermosillo, Sonora, México, C. P. 83100. \\ * Correspondence: jesus.moreno@ciad.mx
}

\begin{abstract}
Objective. To validate a simulation model which enables the estimation of wheat (Triticum aestivum L.) production, based on climatic variables in the lower Mayo River basin in Sonora, Mexico.

Design/methodology/approach. The Soil and Water Assessment Tool (SWAT) Crop Yield simulation model was used to estimate productive wheat yields. The model was fed with climatic data for the 1979-2014 period, provided by the National Centers for Environmental Prediction. Subsequently, the results were validated using the Nash-Sutcliffe, PBIAS, and $\mathrm{R}^{2}$ statistics. The predictive capacity of the model was validated in four of the six Hydrological Response Units with agricultural land in the study area: 26, 27, 28, and 31 .

Study limitations/implications. The model does not include adaptation measures and future production scenarios based on climate data estimation must be developed.

Findings/conclusions. The influence of climate change on wheat production has been confirmed; the predictive model used is an important tool that can be adjusted and adapted to other regions and production systems.
\end{abstract}

Keywords: Climate change, farming, wheat, SWAT model.

Citation: Salazar-Solano, V., Moreno-

Dena, J. M., Rojas-Rodríguez, I. S., \&CDe La Torre-Valdez, H. C. (2022). Validation of a model to estimate climate effects on wheat (Triticum aestivum L.) production in a hydrological basin. Agro Productividad. https://doi.org/10.32854/agrop. v15il.2136

Editor in Chief: Dr. Jorge Cadena Iñiguez

Received: September 27, 2021 Accepted: January 10, 2021. Published on-line: January, 2022

This work is licensed under a Creative Commons Attribution-NonCommercial 4.0 International license.

\section{INTRODUCTION}

The countries that signed the Paris Agreement in 2016 accepted that "the fundamental priority of safeguarding food security and ending hunger, and the particular vulnerabilities of food production systems to the adverse effects of climate change" (Food and Agriculture Organization of the United Nations (FAO) (FAO, 2017)). This commitment endorsed previous scientific positions that warned that the climate, in addition to being an essential determinant of agricultural productivity, was also its main source of risk (Antle, 2008). It was only until the late 20th century, that scientific activity developed models of the economic impact that climatic variations have on food production (Adams, 1989; Kane et al., 1992; Mendelsohn et al., 1994). Subsequently, analysis based on simulation models (Rötter et al., 2018) confirmed the negative impact of climate on crop productivity (Intergovernmental Panel on Climate change (IPCG), 2019). Based on the exploration of tendencies, some 
researchers predict sensitive repercussions in the food sector; Field et al. (2014), Huong et al. (2019), Mendelsohn et al. (2010), and Nelson et al. (2018) warn that, in the course of the 21 st century, the effects of climate change could restrict: a) economic growth, b) food security, and c) the success of poverty reduction efforts. Given this scenario, it is increasingly important to develop appropriate methodologies that support the adjustment of agricultural activity, depending on the challenges presented by the modification of environmental factors, specifically those related to climate change.

\section{Impact of climate change on wheat production}

Since the late 20th century, the argument for the negative effect of climate change on cereal production has been raised; scientists have warned that it will increase over the course of the 21st century (Rosenzweig and Parry, 1994). The most outstanding studies in this field include studies about the production of wheat - a crop that has been a staple food of humanity since the birth of civilization. Currently, 765 million tons of this grain are produced (FAO, 2021), confirming its historical relevance along with corn and rice.

The study carried out by Mereu et al. (2021) stands out among the recent studies about the estimation of the impact of climate change on wheat cultivation. They used a simulation model to evaluate the effects of climate change on the production of durum and common wheat in Italy; their findings suggest that yields would decline mainly in southern Italy, while the north would benefit from higher rainfall regimes. In addition to temperature and precipitation, Zhang et al. (2017) included the following variables in their analysis: humidity, wind, and solar radiation. They estimated the degree to which these variables influenced wheat productivity. Their results reveal that climate change could negatively impact its production in China by up to $18.26 \%$ by the end of this century.

Pequeno et al. (2021) and other authors simulated climate change impacts and global adaptation strategies for wheat, using new crop genetic traits -including increased heat tolerance and traits combined with additional nitrogen fertilizer applications-, as an option to maximize genetic gains. Their results predict that climate change will reduce global wheat production by $1.9 \%$ by mid-century. Hernández-Ochoa et al. (2018) projected wheat production in Mexico for 2050 simulating five climatic environments. All the scenarios reported yields falls, linked to the increase in temperatures; in rare cases, increases in production are explained by rainfall. Despite the vast range of studies on the subject, specific methodological strategies must be explored for each productive region to allow progress in climate change adaptation and mitigation issues. Within these lines of research, this article aims to validate a simulation model that estimates wheat production, based on climatic variables in the lower Mayo River basin in Sonora, Mexico.

\section{MATERIALS AND METHODS}

The analysis area is the lower sub-basin of the Mayo River $\left(5,397 \mathrm{~km}^{2}\right)$, part of the Mayo River basin in Sonora, Mexico. It begins in the Adolfo Ruiz Cortines dam and its mouth flows into the Gulf of California (Figure 1). This space concentrates the substantive factors for wheat production, its main crop in terms of extension (62\%) and value (46\%) (Sistema de Información Agroalimentaria y Pesquera (SIAP), 2021). 

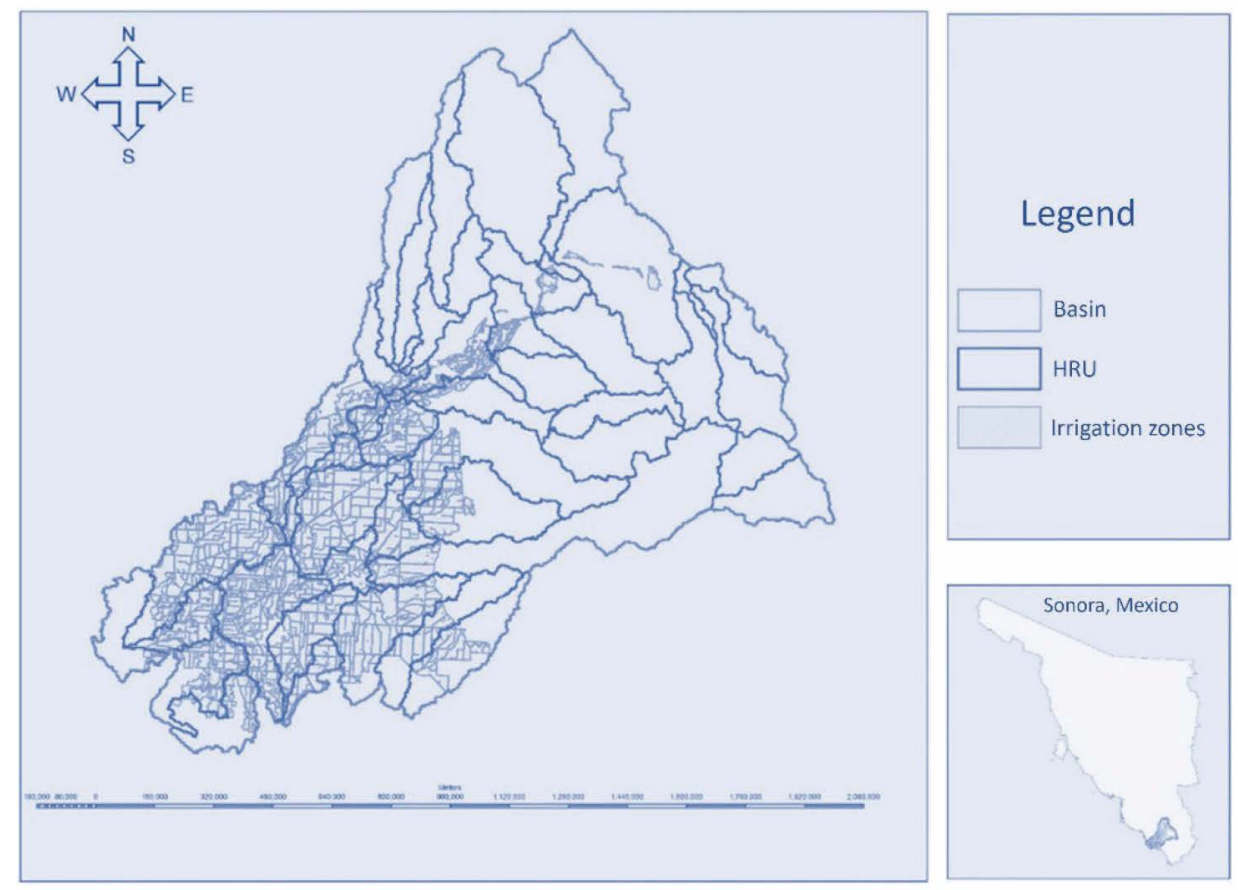

Figure 1. Mayo River Lower Basin.

\section{Description of the applied model}

The estimation of the variations in the productive yields of wheat was carried out based on an analysis structure supported by the Soil and Water Assessment Tool (SWAT) Crop Yield simulation model. It predicts the impact of soil and water management practices on processes such as sediment generation, erosion, and agricultural yields in a basin complex, with a variety of soils, land use, and management conditions over long periods (Neitsch et al., 2011). In physical terms, SWAT operates at the basin scale in continuous time, establishing the following parameters for daily simulations: hydrology, soil, use, a digital elevation model, and climate data. The model's components include climate, hydrology, soil temperature, plant growth, nutrients, pesticides, and land management. Based on the spatially explicit parameterization, the model divides the territory into subbasins. In their turn, the sub-basins are divided into hydrological response units (HRUs), according to specific land type and use (Akhavan et al., 2010).

The HRUs represent homogeneous spaces according to the area's soil types and uses, vegetation cover, and slope. The disaggregation of the sub-basin into smaller entities allows the model to reflect differences in evapotranspiration, soil types, vegetation covers, and their generation (Akhavan et al., 2010). In total, 31 HRUs make up the lower Mayo River basin; however, only six match agricultural soils; therefore, they constitute the core points of interest of this research. These are the 23, 26, 27, 28, 30, and 31 HRUs.

The SWAT model uses a digital elevation model (DEM) map to describe the watershed and its Hydrologic Response Units. The Continuo de Elevaciones Mexicano 3.0 (Instituto Nacional de Estadística y Geografía (INEGI), 2021) was used for this purpose. 
The land-use maps were obtained from the Portal de Geo información (Comisión Nacional para el Conocimiento y la Biodiversidad (CONABIO) (CONABIO, 2021)). Vector land use and vegetation data sets (scale 1:250,000 - series V) were used to classify the different soil types into hydrological groups, based on infiltration characteristics (CONABIO, 2021).

\section{Cultivation, sowing dates, irrigation, and fertilizer application}

Forty winter wheat biophysical traits identified by SWAT were considered for wheat yield simulations. Based on the autumn-winter cycle technological package for wheat in Sonora (Instituto Nacional de Investigaciones Forestales, Agrícolas y Pecuarias (INIFAP), 2017), this crop is established on November 15 of each year and ends on May 2 of the following year. The volumes and dates of application of irrigation and fertilizers also come from the information contained in the above-mentioned technological package.

\section{Weather}

The Model was fed with the records of the Climate Forecast System Reanalysis (CFSR), obtained by the National Centers for Environmental Prediction (NCEP) over a 35-year period (1979-2014). In the study area, information was obtained from six weather stations; temperature records (maximum and minimum), precipitation, relative humidity, wind, and solar radiation were monitored daily. The information (including its georeferencing) was incorporated into the database entered into the model.

\section{Model validation}

To validate the model, the estimated data of the 23, 26, 27, 28, 30, and 31 HRUs were contrasted with data observed in the Distrito de Desarrollo Rural (DDR) de Navojoa, taking into account the regionalization made by Secretaría de Agricultura y Desarrollo Rural (SADER) for the 1992-2003 period. The six HRUs are located within the DDR territory; however, since there is no accurate production information for each of them, the information will be contrasted with the district's aggregate production data. Validation was performed based on three procedures or statistics:

a. Nash-Sutcliffe efficiency (NSE), which is expressed as:

$$
N S E=1.0-\sum_{t=1}^{T} \frac{\left(y_{t}-f_{t}\right)^{2}}{\sum_{t=1}^{T}\left(y_{t}-\bar{y}\right)^{2}}
$$

indicating how well the observed versus simulated data set fits the 1:1 line. It ranges between $-\infty$ and 1 , with $\mathrm{NSE}=1$ being the optimal value. Values between 0.0 and 1.0 are generally considered to be acceptable performance levels, while $<0.0$ values indicate that the mean observed value is a better predictor than the simulated value, indicating unacceptable efficiency (Moriasi et al., 2013). 
b. PBIAS, expressed as:

$$
\text { PBIAS }=\left(\frac{\sum_{t=1}^{T}\left(f_{t}-y_{t}\right)}{\sum_{t=1}^{T} y_{t}}\right) * 100
$$

where $f_{t}$ is the simulated value of the model at time $t ; y_{t}$ is the data value observed at time $t(t=1,2, \ldots, T)$. PBIAS measures the average tendency of the simulated data to be larger or smaller than the observed data (Gupta et al., 1999). Small-magnitude $P B I A S$ values are preferred. Positive values indicate an overestimation bias of the model and negative values, an underestimation bias (Gupta et al., 1999).

c. $\mathrm{R}^{2}$, represented by the following equation:

$$
R^{2}=\left\{\frac{\sum_{t=1}^{T}\left(y_{t}-\bar{y}\right)\left(f_{t}-\bar{f}\right)}{\left[\sum_{t=1}^{T}\left(y_{t}-\bar{y}\right)^{2}\right]^{0.5}\left[\sum_{t=1}^{T}\left(f_{t}-\bar{f}\right)^{2}\right]^{0.5}}\right\}^{2}
$$

where $\bar{y}$ is the mean of the observed data values for the entire evaluation period and $\bar{f}$ is the mean of the simulated data values for the same period. The other symbols have the same meanings defined for the above equation. The value of $R^{2}$ is equal to the square of the Pearson product-moment correlation coefficient (Legates and McCabe Jr., 1999). $R^{2}$ has a range from 0.0 to 1.0 . The highest values are equivalent to better model performance.

\section{RESULTS AND DISCUSSION}

The predictive model of the wheat production behavior generated estimates for six of the 31 HRUs identified in the lower Mayo River basin: 23, 26, 27, 28, 30, and 31. Since the model overestimated the productive yields of wheat, the information was presented as production indexes, which contribute to forecast the behavior of the dependent variable (productive yield), based on the independent variables (specifically, weather) (Table 1).

\begin{tabular}{|c|c|c|c|c|}
\hline \multirow{2}{*}{ Region } & \multicolumn{2}{|c|}{ Average } & \multicolumn{2}{|c|}{ Standard deviation } \\
\hline & Observed & Estimated & observed & Estimated \\
\hline HRU23 & \multirow{6}{*}{0.9545} & 1.1483 & \multirow{6}{*}{0.0792} & 0.2969 \\
\hline HRU26 & & 0.9425 & & 0.0658 \\
\hline HRU27 & & 0.9423 & & 0.0658 \\
\hline HRU28 & & 0.9394 & & 0.0823 \\
\hline HRU30 & & 1.2656 & & 0.3515 \\
\hline HRU31 & & 0.9389 & & 0.0797 \\
\hline
\end{tabular}

Table 1. Production index (1992-2003).

Source: Own elaboration. 
The first analysis identifies similar behaviors between estimated and observed production in four of the six HRUs analyzed: 26, 27, 28, and 31. In contrast, the 23 and 30 HRUs have divergent results. For validation, three statistics were calculated: Nash-Sutcliffe efficiency, PBIAS (bias), and $\mathrm{R}^{2}$ (Table 2).

The calculation of these statistics confirmed, by inference, the analysis of the mean and standard deviation. The predictive capacity of the model is validated in the 26, 27, 28, and 31 HRUs. In the case of Nash Sutcliffe, a $>0$ coefficient is considered acceptable. Meanwhile a $<20 \%$ BIAS probability is enough, and the closer that $\mathrm{R}^{2}$ is to unity, the greater the resemblance between the real and observed behavior of the variable. A graph of the similarities can be seen in Figure 2. Once the predictive structure was validated, the influence of climatic variables on wheat production was analyzed. A seven-climatic variable Pearson correlation analysis was carried out for the 1980-2013 period (Table 3), confirming their influence on the behavior of the productive yields of the crop. On the one hand, precipitation and evapotranspiration were directly related to wheat yields: the

Table 2. Statistics used for model validation.

\begin{tabular}{c|c|c|c}
\hline RHU & Nash-Sutcliffe & PBIAS & $\mathbf{R}^{\mathbf{2}}$ \\
\hline HRU23 & -77.5 & $-273.00 \%$ & 0.2825 \\
\hline HRU26 & 0.7 & $12.80 \%$ & 0.7991 \\
\hline HRU27 & 0.69 & $13.10 \%$ & 0.7995 \\
\hline HRU28 & 0.53 & $17.30 \%$ & 0.5584 \\
\hline HRU30 & -201.25 & $-434.40 \%$ & 0.6453 \\
\hline HRU31 & 0.49 & $18.30 \%$ & 0.6675 \\
\hline
\end{tabular}

Source: Own elaboration.

HRU 26

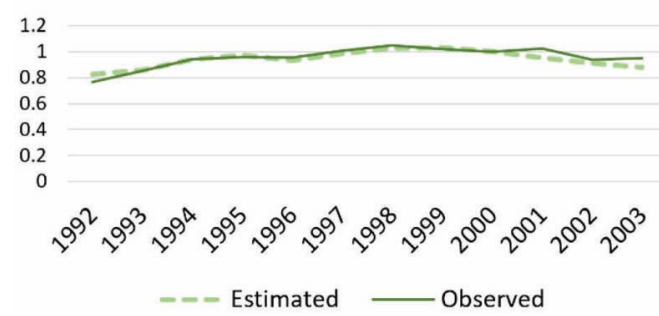

HRU 28

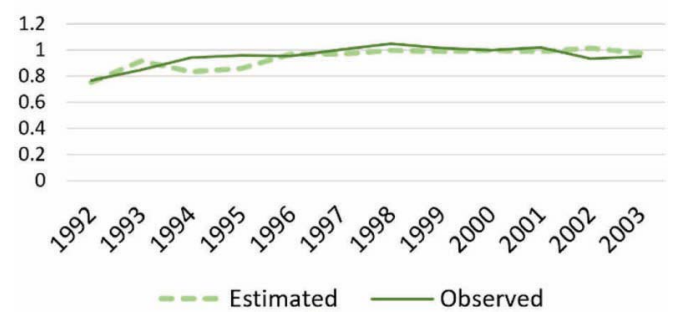

Figure 2. Wheat production index. Selected HRUs.
HRU 27

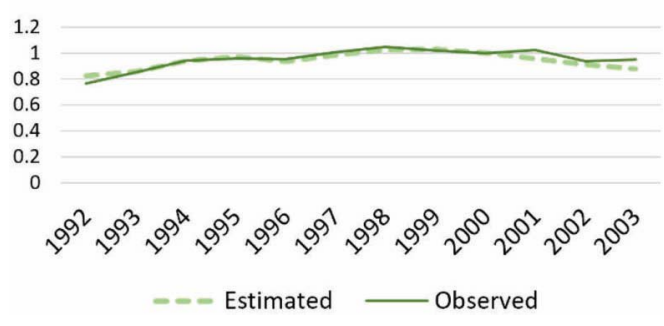

HRU 31

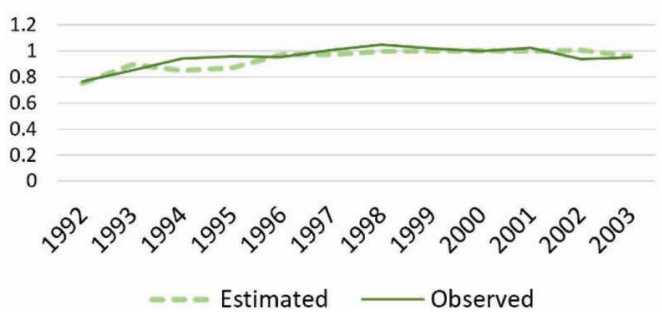


Table 3. Correlation coefficients between productive yields and climatic variables.

\begin{tabular}{|c|c|c|c|c|c|c|c|}
\hline \multirow{3}{*}{ RHU } & \multirow{3}{*}{$\begin{array}{c}\text { Annual } \\
\text { precipitation }\end{array}$} & \multirow[t]{3}{*}{ Evapotranspiration } & \multicolumn{4}{|c|}{ Temperature } & \multirow{3}{*}{$\begin{array}{c}\text { Solar } \\
\text { radiation } \\
\left(\mathbf{J} / \mathbf{m}^{2}\right)\end{array}$} \\
\hline & & & $\begin{array}{l}\text { Annual } \\
\text { average }\end{array}$ & $\begin{array}{c}\text { Annual } \\
\text { maximun }\end{array}$ & $\begin{array}{c}\text { Annual } \\
\text { minimum }\end{array}$ & $\begin{array}{c}\text { soil } \\
\text { average }\end{array}$ & \\
\hline & & & \multicolumn{4}{|c|}{$\left({ }^{\circ} \mathbf{G}\right)$} & \\
\hline HRU23 & 0.44 & 0.65 & -0.47 & -0.53 & -0.33 & -0.49 & -0.46 \\
\hline HRU26 & 0.27 & 0.57 & -0.31 & -0.36 & -0.21 & -0.58 & -0.33 \\
\hline HRU27 & 0.27 & 0.57 & -0.31 & -0.36 & -0.21 & -0.58 & -0.33 \\
\hline HRU28 & 0.24 & 0.71 & -0.28 & -0.32 & -0.2 & -0.52 & -0.28 \\
\hline HRU30 & 0.39 & 0.63 & -0.48 & -0.54 & -0.35 & -0.5 & -0.43 \\
\hline HRU31 & 0.24 & 0.71 & -0.28 & -0.32 & -0.2 & -0.52 & -0.28 \\
\hline
\end{tabular}

Source: This table was developed by the authors.

higher the precipitation and the evapotranspiration level, the higher the yields. On the other hand, the temperature and solar radiation variables show an inverse relationship.

These results are consistent with those obtained by Hernandez-Ochoa et al. (2018) and Mereu et al. (2021), who highlighted the importance of temperature for the productive yields of wheat. However, the highest correlations in temperature of the 23 and 30 HRUs were not statistically significant; this could be explained by the annual precipitation, which was higher in both cases. These results match the findings of Zhang et al. (2017), who determined that other climatic variables (such as evapotranspiration and solar radiation) impact wheat yields. One of the advantages of this model is the ease with which various climatic variables can be incorporated. In contrast, most academic literature mainly focuses on the effects of temperature and precipitation. This work does not consider technological change or adaptation measures; the introduction of this type of strategy helps to mitigate the effects of climate change (Pequeno et al., 2021), hence the importance of its incorporation in the modeling assumptions. However, this does not lessen the depth of our results.

The use of environmental simulation models is a tool to estimate changes in wheat yields, using a structure that - unlike models emanating from conventional economics - takes the environment into consideration, as one of the factors that determines the production of agricultural systems. The influence of the climate on the development of the wheat crop ultimately impacts its yields and profitability. In this sense, an intense generation of scientific knowledge has been motivated by the search for substantive solutions to prevent and remedy the effects of its vulnerability to climate change.

\section{CONGLUSIONS}

The influence of climate change on wheat production has been corroborated. As part of these academic efforts, this work validated a procedure that confirms the influence of climate change on the production system. In this process, areas of opportunity were identified to be covered in later stages of the overall research process, involving, among other aspects: a) developing productive yield scenarios, based on the estimation of climatic data; b) strengthening the accuracy of the predictive capacities of the model, in terms of 
productive yields; c) incorporating the effects of technological change; and d) replicating the use of the model in other agricultural production systems and water spaces.

\section{REFERENGES}

Adams, R. M. (1989). Global Climate change and Agriculture: An Economic Perspective. American Journal of Agricultural Economics, 71(5), 1272-1279. https://doi.org/10.2307/1243120

Akhavan, S., Abedi-Koupai, J., Mousavi, S.-F., Afyuni, M., Eslamian, S.-S., \& Abbaspour, K. C. (2010). Application of SWAT model to investigate nitrate leaching in Hamadan-Bahar Watershed, Iran. Agriculture, Ecosystems E Environment, 139(4), 675-688. https://doi.org/10.1016/j.agee.2010.10.015

Antle, J. M. (2008). Climate change and Agriculture: Economic Impacts. 3.

Comisión Nacional para el Conocimiento y la Biodiversidad(CONABIO). (2021, marzo 24). Portal de Información Geográfica. Comisión Nacional para el Conocimiento y Uso de la Biodiversidad (CONABIO). http:// www.conabio.gob.mx/informacion/gis/

Field, C. B., Barros, V. R., \& Intergovernmental Panel on Climate change (Eds.). (2014). Climate change 2014: Impacts, adaptation, and vulnerability: Working Group II contribution to the fifth assessment report of the Intergovernmental Panel on Climate change. Cambridge University Press.

Gupta, H. V., Sorooshian, S., \& Yapo, P. O. (1999). Status of Automatic Calibration for Hydrologic Models: Comparison with Multilevel Expert Calibration. Journal of Hydrologic Engineering, 4(2), 135-143. https:// doi.org/10.1061/(ASCE)1084-0699(1999)4:2(135)

Hernandez-Ochoa, I. M., Asseng, S., Kassie, B. T., Xiong, W., Robertson, R., Luz Pequeno, D. N., Sonder, K., Reynolds, M., Babar, M. A., Molero Milan, A., \& Hoogenboom, G. (2018). Climate change impact on Mexico wheat production. Agricultural and Forest Meteorology, 263, 373-387. https://doi.org/10.1016/j. agrformet.2018.09.008

Huong, N. T. L., Bo, Y. S., \& Fahad, S. (2019). Economic impact of climate change on agriculture using Ricardian approach: A case of northwest Vietnam. Journal of the Saudi Society of Agricultural Sciences, 18(4), 449-457. https://doi.org/10.1016/j.jssas.2018.02.006

Instituto Nacional de Estadística y Geografía (INEGI). (2021). Datos de relieve. https://www.inegi.org.mx/app/ geo2/elevacionesmex/

Instituto Nacional de Investigaciones Forestales, Agrícolas y Pecuarias (INIFAP). (2017). Paquete tecnológico del cultivo de trigo O.I. 2017-2018. INIFAP.

Intergovernmental Panel on Climate change (IPCC). (2019). Special Report on Climate change and Land-IPCC site. https://www.ipcc.ch/srccl/

Kane, S., Reilly, J., \& Tobey, J. (1992). An empirical study of the economic effects of climate change on world agriculture. Climatic Change, 27(1), 17-35. https://doi.org/10.1007/BF00143251

Legates, D. R., \& McCabe Jr., G. J. (1999). Evaluating the use of "goodness-of-fit" Measures in hydrologic and hydroclimatic model validation. Water Resources Research, 35(1), 233-241. https://doi. org/10.1029/1998WR900018

Mendelsohn, R., Arellano-Gonzalez, J., \& Christensen, P. (2010). A Ricardian analysis of Mexican farms. Environment and Development Economics, 15(2), 153-171. https://doi.org/10.1017/S1355770X09990143

Mendelsohn, R., Nordhaus, W. D., \& Shaw, D. (1994). The Impact of Global Warming on Agriculture: A Ricardian Analysis. The American Economic Review, 84(4), 753-771.

Mereu, V., Gallo, A., Trabucco, A., Carboni, G., \& Spano, D. (2021). Modeling high-resolution climate change impacts on wheat and maize in Italy. Climate Risk Management, 33, 100339. https://doi.org/10.1016/j. crm.2021.100339

Moriasi, D. N., Gowda, P. H., Arnold, J. G., Mulla, D. J., Ale, S., \& Steiner, J. L. (2013). Modeling the impact of nitrogen fertilizer application and tile drain configuration on nitrate leaching using SWAT. Agricultural Water Management, 130, 36-43. https://doi.org/10.1016/j.agwat.2013.08.003

Neitsch, S., Arnold, J., Kinry, J. R., \& Williams, J. R. (2011). Soil and water assessment tool theoretical documentation. Version.

Nelson, G., Bogard, J., Lividini, K., Arsenault, J., Riley, M., Sulser, T. B., Mason-D’Croz, D., Power, B., Gustafson, D., Herrero, M., Wiebe, K., Cooper, K., Remans, R., \& Rosegrant, M. (2018). Income growth and climate change effects on global nutrition security to mid-century. Nature Sustainability, 1(12), 773-781. https://doi.org/10.1038/s41893-018-0192-z

Organización de las Naciones Unidad para la Alimentación y la Agricultura (FAO). (2021). FAOSTAT. Datos sobre alimentación y agricultura. http://www.fao.org/faostat/es/\#home

Organización de las Naciones Unidas para la Alimentación y la Agricultura (FAO). (2017). La estrategia de la FAO sobre el cambio climático (p. 52). http://www.fao.org/3/i7175s/i7175s.pdf 
Pequeno, D. N. L., Hernández-Ochoa, I. M., Reynolds, M., Sonder, K., MoleroMilan, A., Robertson, R. D., Lopes, M. S., Xiong, W., Kropff, M., \& Asseng, S. (2021). Climate impact and adaptation to heat and drought stress of regional and global wheat production. Environmental Research Letters, 16(5), 054070. https://doi.org/10.1088/1748-9326/abd970

Rosenzweig, C., \& Parry, M. L. (1994). Potential impact of climate change on world food supply. Nature, 367(6459), 133-138. https://doi.org/10.1038/367133a0

Rötter, R., Hoffmann, M., Koch, M., \& Müller, C. (2018). Progress in modelling agricultural impacts of and adaptations to climate change. Current Opinion in Plant Biology, 45, 255-261. https://doi.org/10.1016/j. pbi.2018.05.009

Sistema de Información Agroalimentaria y Pesquera (SIAP). (2021). Producción anual agrícola. https://nube.siap. gob.mx/cierreagricola/

Zhang, P., Zhang, J., \& Chen, M. (2017). Economic impacts of climate change on agriculture: The importance of additional climatic variables other than temperature and precipitation. Journal of Environmental Economics and Management, 83, 8-31. https://doi.org/10.1016/j.jeem.2016.12.001 